\title{
A cross-sectional study of pulmonary function tests among the municipal street sweepers of Chitradurga District, Karnataka
}

\author{
Basavaraj Sangolli ${ }^{1}$, Rashmi BM ${ }^{2, *}$, Sujay Jagadish ${ }^{3}$, Sreeharsha $^{4}$, Chaitra B. ${ }^{5}$ \\ ${ }^{1}$ Assistant Professor, Dept. of Pulmonary Medicine, ${ }^{2}$ Assistant Professor, Dept. of Community Medicine, ${ }^{3}$ Senior Resident, Dept. \\ of Pulmonary Medicine, ${ }^{4}$ Medical Officer-MC, RNTCP, ${ }^{5}$ Junior Resident, Dept. of General Medicine, Basaveshwara Medical \\ College \& Hospital, Chitradurga, Karnataka, India
}

*Corresponding Author:

Email: dr.rashmi.bgm@gmail.com

\begin{abstract}
Municipal street sweepers are exposed to large amount of dusts, microorganisms, toxins and automobile exhaust pollution. Chronic inhalation of such particulate matter has the potential to impair their pulmonary functions. The strict adherence to the standards and norms for the management of municipal solid wastes to reduce occupational health hazards in developing countries India is still a matter of concern. This study conducted among the municipal sweepers of Chitradurga district, compared the effects of chronic exposure to dust on the pulmonary function using spirometry test. This study also assessed the effects of smoking and irregular usage of protection masks, and compared the results with the healthy controls. Respiratory symptoms of cough $(30 \%)$, chest pain $(17.5 \%)$, catarrah and sneezing $(21.5 \%)$ were found to be in higher percentage among the municipal street sweepers than the controls. Only $20 \%$ of participants municipal street sweepers used personal protective measures, wearing protective masks, regularly in the past 1 year, during sweeping streets. It was found that FEV1, FEV1/FVC, PEFR and FEF 25\%$75 \%$ were significantly lesser among non-smoker street sweepers, when compared with that of non-smoking controls. Similarly these PFT values were significantly reduced among the smoker street sweepers and among the sweepers who didn't use protective masks while sweeping. This study highlights the occupational hazard faced by municipal sweepers and attempts to emphasize on importance of usage of protective masks.
\end{abstract}

Keywords: Street sweepers; Personal Protective Measures; Dust; Spirometry.

\section{Introduction:}

Chronic exposure to air pollution and ambient particulate matter (PM) has been found to be associated with increased rates of hospitalization and mortality due to respiratory illnesses. Short term exposure to PM is being found to be associated with impaired forced expiratory volume in 1 second (FEV1) [1]. Sweeping with brooms, vehicular movements and other human activities, raise the dust particles in the air [2,4]. Street sweepers, who play an important role in maintaining the health and hygiene in communities, are chronically exposed to dust particles $[2,4]$.

Paved road dust found on the streets consists of a mixture of soil, sand particles, microorganisms, motor vehicle exhaust particles, plant remnants and other biological materials [5,6]. Municipal sweepers are exposed to such pollutants. The dust particles and Bioaerosols are either swallowed or coughed out to the exterior but the smaller particles between 1-5 micrometers settle down in the smaller bronchioles as a result of gravitational precipitation. Particles smaller than 1 micron in diameter diffuse in the wall of the alveoli and adhere to alveolar fluid, further then taken up by alveolar macrophages which later on lead to tissue destruction. Even though strict adherence to the standards and norms for the management of municipal solid wastes have substantially reduced the occupational health hazards in industrialized countries, this area is still a matter of concern in developing countries $[2,4]$.
Studies have linked chronic exposure to dust from heavy traffic to varying degrees of airway obstruction and respiratory symptoms in man. A high incidence of cough, chronic bronchitis, asthma, sneezing and eye irritation coupled with infection of the throat has also been reported $[3,5,6]$.

The present study was undertaken among municipal sweepers of Chitradurga district, with the following objectives: a) To study the lung functions of sweepers in terms of Forced Vital Capacity (FVC), Forced Expiratory Volume in the first second (FEV1), Ratio of FEV1 /FVC, Forced Expiratory Flow in the middle half of FVC (FEF25-75) and Peak Expiratory Flow Rate (PEFR). b) To study the similar lung function parameters of appropriately matched controls. c) To compare the results of the above two groups. d) To compare the lung functions within municipal workers group, subgrouped according to their smoking habits and following of personal protection measures like masks.

\section{Material and Methods:}

This cross sectional study was conducted in Basaveshwara Medical College \& Hospital, Chitradurga in the month of February-March 2018, after obtaining the ethical clearance from the institutional ethics committee. Permission was taken by the District Municipality Head, before enrolling all municipal workers involved in sweeping, from across the district. Municipal sweepers who were working 
since past 5 years, were included in the study as cases. Those people with history of any Upper Respiratory Tract Infection (URTI) within 2 weeks prior to testing or having chronic medical illnesses (Diabetes, Hypertension, Renal diseases, known chronic respiratory ailments like tuberculosis, COPD etc.) were excluded from the study.

The enrolled workers were explained the purpose of the study and the briefed about the involved noninvasive technique in the study. The workers who gave informed consent were included in the study as cases. Age and sex matched controls, were the conservancy loaders working in municipality, whose occupation did not involve exposure to dust. They were included in the study after obtaining informed consent. A semistructured proforma consisting of socio-demographic profile, personal history, smoking history, usage of personal protective measures was administered to participants, which was filled by insvestigator interview technique, followed by routine clinical examination of the participants, so as to avoid the confounding factors.

Pulmonary Function Test (PFT) was done with the help of computerized spirometry machine, Helios 720 with built in printer in sitting-posture, wearing a nose clip and breathing through mouth-piece. All the cases and controls (A total of 80 municipal sweepers and 50 controls) who fulfilled the study eligibility criteria, underwent pulmonary function test. The Spirometric parameters were measured, the best value of three attempts was taken and all the data with flow-volume and volume-time curves were printed out by the built in printer. The readings of FVC (Forced Vital Capacity), FEV1 (Forced Expiratory volume in first second), Forced Expiratory Flow at $25 \%-75 \%$ of volume as percentage of Vital Capacity (FEF 25\%-75\%), FEV1/
FVC, PEFR (Peak expiratory Flow rate) were noted. The recommendations of American Thoracic society (ATS)/ERS task force series were followed while performing Spirometry $[2,7]$.

\section{Statistical Analysis:}

The data was checked for normality of distribution using Kolmogorov Smirnov test. All the characteristics are summarized descriptively. For continuous variables, the summary statistics of $\mathrm{N}$, mean, standard deviation about the arithmetic mean were used. For categorical data, the number and percentage were used in the data summarized.

The difference in the mean pulmonary function test values of FEV1, FVC, PEFR, FEF 25\%-75\% among cases and controls was analysed using unpaired 2-tailed Student's t-test. Chi square test was applied to test significance of association of categorical variables among the groups.

Data was compiled in Microsoft excel spread sheets and analyzed using SPSS for windows version 16.0. A $\mathrm{p}$ value $<0.05$ was considered statistically significant.

\section{Results:}

A total of 80 municipal street sweepers and 50 controls participated in the study. Among the 80 street sweepers, $57(71.3 \%)$ were males and $23(28.75 \%)$ were females. A $52.6 \%$ of street sweeper males were smokers who smoked beedi/cigarettes regularly in the past 2 years. Only a 20\% of municipal sweeper participants used personal protective measures wearing protective masks, regularly in the past 1 year, during sweeping streets. (Table 1)

Table 1: Basic characteristics of municipal sweepers

\begin{tabular}{|c|c|c|c|}
\hline $\begin{array}{c}\text { Basic } \\
\text { characteristics of } \\
\text { municipal sweepers }\end{array}$ & $\begin{array}{c}\text { Males }(\mathbf{n}=57) \\
\text { Mean } \pm \text { SD } \\
\text { n }(\%)\end{array}$ & $\begin{array}{c}\text { Females }(\mathbf{n}=23) \\
\text { Mean } \pm \text { SD } \\
n(\%)\end{array}$ & $\begin{array}{c}\text { Total } \\
\mathbf{N}(\%)\end{array}$ \\
\hline Age & $36.8 \pm 6.4$ years & $34.9 \pm 5.7$ years & \\
\hline \multicolumn{4}{|l|}{ Smoking habits } \\
\hline Smokers & $30(52.6 \%)$ & $0(0)$ & $30(37.5 \%)$ \\
\hline Non smokers & $27(47.4 \%)$ & $23(100.0 \%)$ & $50(62.5 \%)$ \\
\hline \multicolumn{4}{|c|}{ Personal protective measures (Usage of protective mask) } \\
\hline Regular & $7(12.3 \%)$ & $9(39.1 \%)$ & $16(20 \%)$ \\
\hline Irregular & $50(87.7 \%)$ & $14(60.9 \%)$ & $64(80 \%)$ \\
\hline Total & $57(100.0 \%)$ & $23(100.0 \%)$ & $80(100 \%)$ \\
\hline
\end{tabular}




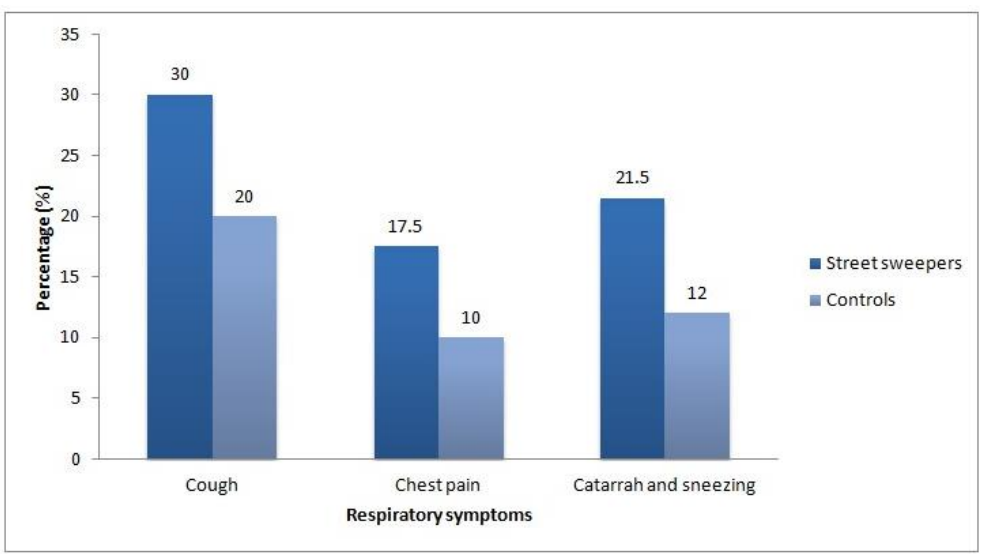

Fig. 1: Comparison of respiratory symptoms among cases and controls

Fig. 1 illustrates the comparison of respiratory symptoms observed among the municipal street sweepers and controls. Respiratory symptoms [cough (30\%, chest pain $(17.5 \%)$, catarrah and sneezing (21.5\%)] were found in higher percentage among municipal street sweepers as compared with the respiratory symptoms among controls [cough (20\%), chest pain (10\%), catarrah and sneezing (12\%)]

Cases and controls were comparable with respect to age, sex, height and weight. It was found that the mean spirometry values of FEV1, FEV1/FVC, PEFR and FEF $25 \%-75 \%$ were significantly reduced among non-smoker street sweepers, when compared with that of non-smoking controls, whereas there was no significant difference in FVC among them. This showed that non-smoker street sweepers who were working for more than 5 years had developed obstructive pattern (FEV1/FVC <80\%) impairment of lung functions. (Table 2)

Table 2: The comparison of non-smoker street sweepers with non-smoker controls

\begin{tabular}{|c|c|c|c|}
\hline Parameters & $\begin{array}{c}\text { Non smoker } \\
\text { Street sweepers } \\
(\mathrm{n}=50) \text { Mean } \pm \text { SD }\end{array}$ & $\begin{array}{l}\text { Non-smoker controls } \\
(n=50) \text { Mean } \pm \text { SD }\end{array}$ & p value \\
\hline Age & $35.8 \pm 6.5$ years & $35.2 \pm 7.1$ years & NS* \\
\hline \multicolumn{4}{|l|}{ Sex } \\
\hline Male & $27(54 \%)$ & $22(44 \%)$ & \multirow[t]{2}{*}{$\mathrm{NS}^{\$}$} \\
\hline Female & $23(46 \%)$ & $28(56 \%)$ & \\
\hline Height & $1.61 \pm 0.03$ & $1.61 \pm 0.02$ & NS \\
\hline Weight & $65.2 \pm 8.3$ & $65.8 \pm 9.4$ & NS \\
\hline \multicolumn{4}{|l|}{ PFT } \\
\hline $\begin{array}{l}\text { FEV1 } \\
\text { (\% predicted) }\end{array}$ & $62.5 \pm 12.7$ & $87.2 \pm 7.4$ & $<0.05^{*}$ \\
\hline $\begin{array}{l}\text { FVC } \\
\text { (\% predicted) }\end{array}$ & $84.2 \pm 13.1$ & $85.7 \pm 12.8$ & NS \\
\hline $\begin{array}{l}\text { FEV1 / FVC } \\
\text { ratio }\end{array}$ & $76.32 \pm 12.8$ & $86.7 \pm 13.5$ & $<0.05^{*}$ \\
\hline $\begin{array}{l}\text { PEFR } \\
\text { (\% predicted) }\end{array}$ & $64.81 \pm 10.1$ & $91.28 \pm 12.7$ & $<0.05^{*}$ \\
\hline FEF $25 \%-75 \%$ & $54.4 \pm 13.9$ & $83.8 \pm 12.6$ & $<0.05^{*}$ \\
\hline
\end{tabular}

*Independent student $t$ test is applied to test the significance of difference in the spirometry values among the two groups; \$: Chi square test is applied to test significance of association among groups.

NS: Not significant

Street sweeper males were categorized into two groups according to their smoking habits and a comparison of their pulmonary functions was made, in order to assess the possible effect of smoking on lung function. It was found that the mean spirometry values of FEV1, PEFR and FEF 25\%-75\% among smoker street sweeper males were significantly reduced as compared to that of non-smoker street sweeper males. FEV1/FVC ratio value was $<80 \%$ among both the groups, the mean values of this ratio among smokers was significantly lesser when compared to non-smoker street sweepers, whereas the FVC was not significantly different between the 2 groups. (Table 3 ) 
Table 3: The comparison of pulmonary function test of Smoker street sweepers with Non-smoker street sweepers (smokers: h/o smoking since past 2 years)

\begin{tabular}{|l|c|c|c|}
\hline \multicolumn{1}{|c|}{ Parameters } & $\begin{array}{c}\text { Smoker Street } \\
\text { sweeper males } \\
(\mathbf{n = 3 0 )} \text { Mean } \pm \text { SD }\end{array}$ & $\begin{array}{c}\text { Non-smoker street } \\
\text { sweeper males } \\
(\mathbf{n = 2 7}) \text { Mean } \pm \text { SD }\end{array}$ & $\begin{array}{c}\mathbf{p} \\
\text { value }\end{array}$ \\
\hline Age & $37.5 \pm 5.3$ years & $36.2 \pm 7.1$ years & NS \\
\hline Height (meters) & $1.62 \pm 0.03$ & $1.63 \pm 0.04$ & $\mathrm{NS}$ \\
\hline Weight (Kgs) & $64.7 \pm 6.1$ & $66.8 \pm 7.5$ & $\mathrm{NS}$ \\
\hline PFT & & & \\
\hline FEV1 (\% predicted) & $54.8 \pm 11.6$ & $57.7 \pm 11.9$ & $<0.05$ \\
\hline FVC $(\%$ predicted) & $83.8 \pm 10.8$ & $85.2 \pm 10.1$ & $\mathrm{NS}$ \\
\hline FEV1 / FVC ratio & $71.90 \pm 13.8$ & $78.32 \pm 13.5$ & $<0.05$ \\
\hline PEFR (\% predicted) & $59.8 \pm 11.7$ & $63.7 \pm 9.3$ & $<0.05$ \\
\hline FEF 25\%-75\% & $49.1 \pm 10.4$ & $53.4 \pm 7.9$ & $<0.05$ \\
\hline
\end{tabular}

*Independent student $\mathrm{t}$ test applied to test the significance of difference among two groups NS: Not significant

Non-smoker municipal street sweepers (both males and females) were also sub-classified based on usage of personal protective masks regularly in the past 2 years. The pulmonary function tests were assessed among regular users of protective masks with the irregular/non-users of the protective masks. It was found that FEV1, FEV1/FVC ratio, PEFR and FEF
25\%-75\% were significantly reduced among the non smoker street sweepers who did not use masks, as compared to that of non-smoker street sweepers who used protective masks regularly while sweeping. Whereas the FVC was not significantly different between the 2 groups. (Table 4 )

Table 4: The comparison of pulmonary function test of street sweepers who used masks regularly with street sweepers who did not use masks regularly in the past 1 year

\begin{tabular}{|c|c|c|c|}
\hline Parameters & $\begin{array}{l}\text { Non-smoker street } \\
\text { sweepers who used } \\
\text { masks regularly in } \\
\text { past } 1 \text { year }(n=16) \\
\text { Mean } \pm \text { SD }\end{array}$ & $\begin{array}{c}\text { Non smoker Street } \\
\text { sweepers who did not use } \\
\text { masks regularly in past } 1 \\
\text { year (n= 34) Mean } \pm \text { SD } \\
\text { Total males: }\end{array}$ & p value \\
\hline Age & $37.5 \pm 5.3$ years & $36.2 \pm 7.1$ years & NS \\
\hline \multicolumn{4}{|l|}{ Sex } \\
\hline Males & 7 & 50 & $\mathrm{P}<0.05$ \\
\hline Females & 9 & 14 & \\
\hline Height (meters) & $1.58 \pm 0.03$ & $1.53 \pm 0.01$ & NS \\
\hline Weight (Kgs) & $65.6 \pm 7.3$ & $65.1 \pm 8.1$ & NS \\
\hline \multicolumn{4}{|l|}{ PFT } \\
\hline FEV1 (\% predicted) & $62.7 \pm 12.4$ & $53.1 \pm 10.9$ & $<0.05$ \\
\hline FVC (\% predicted) & $84.8 \pm 9.7$ & $85.6 \pm 10.4$ & NS \\
\hline FEV1 / FVC ratio & $78.53 \pm 11.9$ & $71.9 \pm 13.8$ & $<0.05$ \\
\hline PEFR (\% predicted) & $70.8 \pm 12.9$ & $60.9 \pm 7.2$ & $<0.05$ \\
\hline FEF $25 \%-75 \%$ & $61.3 \pm 11.7$ & $51.9 \pm 8.6$ & $<0.05$ \\
\hline
\end{tabular}

*Independent student $\mathrm{t}$ test applied to test the significance of difference among two groups

NS: Not significant

\section{Discussion:}

Street sweepers are exposed to large amount of dust particles, microorganisms, toxins and automobile exhaust pollutants. Particulate matter of $<1 \mu \mathrm{m}$ size can reach the smaller bronchioles, diffuse in the alveolar fluids and eventually lead to tissue destruction, further resulting in various lung disorders [2,3]. The use of respiratory protection like face mask is an effective preventive measure to reduce airborne dust entry into lungs during sweeping. The present study was an attempt to assess the prevalence of usage of personal protective measures among the street sweepers and also the effects of long term ( $>5$ years) exposure to dusty environment. It was found that only $20 \%$ of street sweepers wore masks regularly in the past 1 year (Table 1). Similar results of lesser usage or nil usage of personal protective face masks, have been found in studies done elsewhere [6,8]. The prevalence of respiratory symptoms of cough, chest pain, catarrah and sneezing was higher among the street sweepers when compared with the controls (Fig. 1). Similar results are found in the studies conducted by Loftsted et al [9]. 


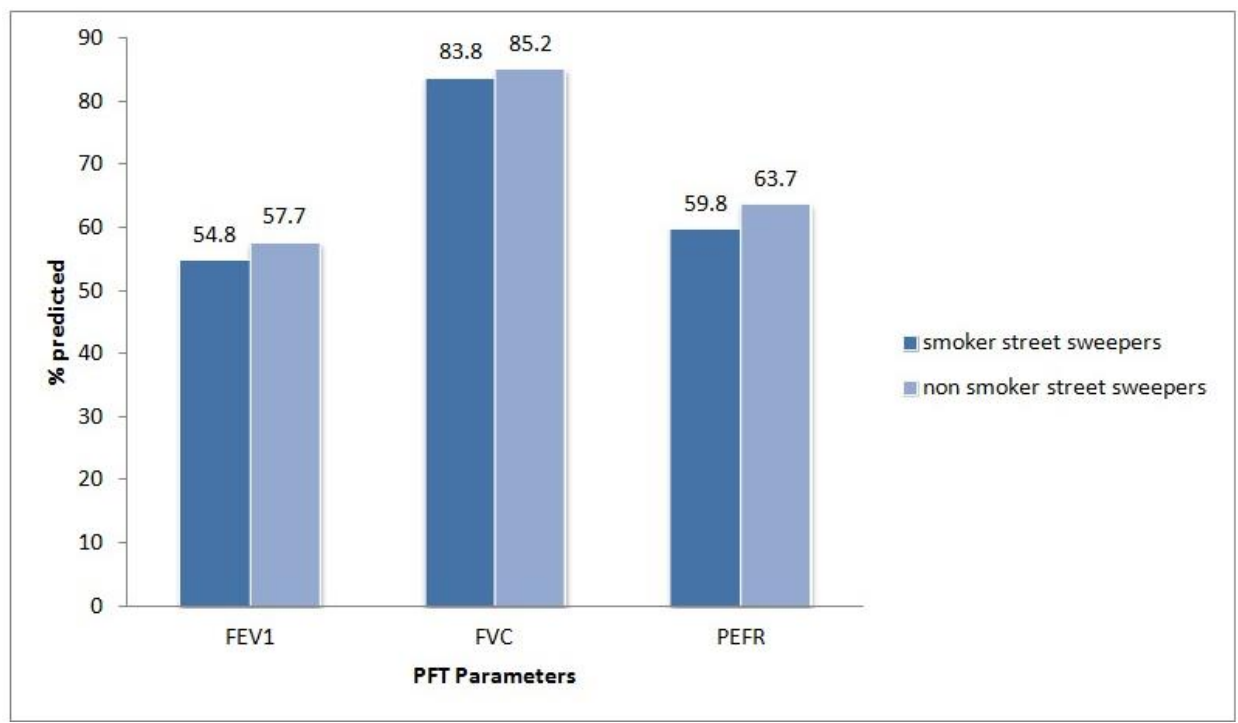

Fig. 2: The comparison of non-smoker street sweepers with non smoker controls

The present study has also shown that mean spirometric values of FEV1, PEFR, FEF 25-75\%, FEV1/FVC ratio among non-smoker street sweepers were significantly lower when compared with the controls. Mean FVC values were not significantly different among the 2 groups of cases and controls. These results indicate that the chronic inhalation of dust in street sweepers in the past 5 years is a significant occupational hazard which has resulted in an obstructive pattern of lung function impairment (FEV1/FVC ratio of $<80 \%$ ). (Table $2 \&$ Fig. 2) The findings of this study are comparable with the studies done by Anwar SK et al, Arora R et al $[6,8]$. The authors have mentioned that inhalation of dust particles which reach the smaller bronchioles, can eventually activate receptors like $\mathrm{c}$ type lectin receptors, protease activated receptors among others, present in the airway epithelial cells, leading to a cascade of immune process, resulting in acute inflammation. It is also hypothesized that the reduction in FEV1 may be due to the loss of elastic recoil pressure of the lungs, which decreases the force required to expel air out of lungs. This phenomenon is due to the microscopic enlargement of air spaces rather than to grossly visible emphysema $[2,6,10-16]$.

The present study also compared the lung function tests among the municipal street sweepers, subcategorized according to their smoking habits and also usage of protective masks during sweeping. It was found that the spirometry values of FEV1, PEFR, FEV1/FVC ratio, FEF $25-75 \%$ were significantly reduced among a) the chronic smoker street sweeper males when compared with the non-smoker street sweeper males, b) among the non smoker street sweepers who did not wear protective masks regularly, as compared with the street sweepers who used such protective masks regularly in the past 2 years (Table 3 and Table 4). Similar results have been found elsewhere $[2,4]$. These results support the hypothesis that smoking is a risk factor for impairment of pulmonary functions and also highlights the importance of regular usage of protective masks during sweeping of streets.

In conclusion, the significantly reduced mean spirometry values among non-smoker municipal sweepers when compared to non-smoker controls, indicate that an obstructive pattern of lung function impairment was present among sweepers. Such occupational diseases may be prevented by adoption of simple measures like using long handled brooms, watering the area before sweeping which assists in the settling of dust particles on the ground $[6,10,11,15]$.

Also, significantly reduced mean spirometry values among smoker street sweepers and among sweepers who did not regularly wear protective masks, support the hypothesis that smoking is a risk factor for impairment of pulmonary functions and the findings also highlight the importance of regular usage of protective masks during sweeping of streets. Although the trend of usage of protective masks while sweeping is being encouraged, the percentage of people following this personal protection is very less. This is also one of the areas that need to be addressed. Even though extensive health awareness creation measures are adopted to generate knowledge in the public about the harmful effects of smoking, there is still a higher prevalence of smokers and there is evidence of the harmful effects of smoking on respiratory system. To achieve human development, to ensure equity in quality of life for all, it becomes utmost important to address these health risks of smoking, chronic exposure to air pollution. 


\section{References:}

1. Baccarelli AA, Zheng Y, Zhang X, Chang D, Liu L, Wolf $\mathrm{KR}$, et al. Air pollution exposure and lung function in highly exposed subjects in Beijing, China: A repeatedmeasure study. Part Fibre Toxicol 2014;11(1).

2. Shadab M, Agrawal DK, Ahmad Z, Aslam M. A cross sectional study of Pulmonary Function Tests in street cleaners in Aligarh, India. Biomed Res-India Biomed Res Biomed Res [Internet]. 2013;24(244):449-52. Available from: http://www.biomedres.info

3. Glovsky MM, Miguel AG CG. Particulate air pollution: possible relevance in asthma. Allergy Asthma Proc 1997;18(3):163-6.

4. Nku CO, Peters EJ, Eshiet AI, Oku O, Osim EE. Lung function, oxygen saturation and symptoms among street sweepers in calabar-Nigeria. Niger J Physiol Sci 2005;20:79-84.

5. Ajay KT, Vatsala AR, Danyakumar G, Bondadae SY. A study of impairment of lung functions in adult sweepers. J Pharm Sci Res 2014;6(6):239-41.

6. Arora R. Lung function response to dust in Safai workers. Int J Med Dent Sci [Internet]. 2016;5(1):1038-41.

Available from: http://ijmds.org/wpcontent/uploads/2015/12/1038-1041-RA-Lungfunction.pdf

7. Miller MR, Hankinson J, Brusasco V, Burgos F, Casaburi $\mathrm{R}$, Coates A, et al. Standardisation of spirometry. 2005;26(2):319-38.

8. Anwar SK, Mehmood N, Nasim N, Khurshid M, Khurshid B. Sweeper's lung disease: A cross-sectional study of an overlooked illness among sweepers of Pakistan. Int J COPD 2013;8:193-7.
9. Löfstedt H, Hagström K, Bryngelsson I-L, Holmström M, Rask-Andersen A. Respiratory symptoms and lung function in relation to wood dust and monoterpene exposure in the wood pellet industry. Ups J Med Sci [Internet]. 2017;122(2):78-84. Available from: https://www.tandfonline.com/doi/full/10.1080/03009734. 2017.1285836

10. Hammad H, Lambrecht BN. Nature Reviews Immunology. Nat Rev Immunol 2008;8:193-204.

11. Fulvio A, Querol X, Alsteuy A, Pandolfi M, Moreno T, Rodriguez P. Evaluating urban PM 10 pollution benefit induced by street cleaning activities. 2009;43:4472-80.

12. Wang J. The Innate Immune Response in House Dust Mite-Induced Allergic Inflammation. 2013;5(138):68-74.

13. Thacker E. Lung inflammatory responses. Vet Res BioMed Cent [Internet]. 2006;37(3):469-86. Available from: https://hal.archives-ouvertes.fr/hal00903034/document

14. Roopa S, Padmavathi R, Akolkar A, Sankar S, Ravishankar P, Vijayalakshmi T, et al. Respiratory functions of conservancy workers working in solid waste management sector of Chennai, India. F1000Research [Internet]. 2013;4-9. Available from: http://f1000research.com/articles/1-67/v2

15. Athanasiou M, Makrynos G, Dounias G. Respiratory health of municipal solid waste workers. 2018;7:618-23.

16. Tiwari R. Occupational health hazards in sewage and sanitary workers. Ind J Occup Environ Med 2008;12(3):12-5.

How to cite this article: Sangolli B., BM Rashmi, Sujay Jagadish S., Sreeharsha, B. Chaitra. A crosssectional study of pulmonary function tests among the municipal street sweepers of Chitradurga District, Karnataka. IP Indian J Immunol Respiratory Med 2018;3(3):108-113. 